\title{
Zircon U-Pb dating confirms existence of a Caledonian scheelite- bearing aplitic vein in the Penggongmiao granite batholith, South Hunan
}

\author{
ZHANG WenLan $^{1}$, WANG RuCheng ${ }^{1 *}$, LEI ZeHeng ${ }^{2}$, HUA RenMin ${ }^{1}$, ZHU JinChu $^{1}$, \\ LU JianJun ${ }^{1}$, XIE Lei ${ }^{1}$, CHE XueDong ${ }^{1}$, ZHANG RongQing ${ }^{1}$, YAO Yuan ${ }^{1} \&$ CHEN Jun ${ }^{1}$ \\ ${ }^{1}$ School of Earth Sciences and Engineering, State Key Laboratory for Mineral Deposits Research, Nanjing University, Nanjing 210093, China; \\ ${ }^{2}$ South Hunan Geological Survey, Chenzhou 423000, China
}

Received January 5, 2011; accepted April 19, 2011

\begin{abstract}
Granite at Penggongmiao is a large batholith in the Nanling Range, with an outcrop area of over $900 \mathrm{~km}^{2}$. There are many scheelite-quartz veins around the granite. LA-ICP-MS U-Pb dating was carried out for zircons from the granite. The middlecoarse-grained biotite granite has U-Pb ages of 435 to $436 \mathrm{Ma}$. Ages of $426.5 \pm 2.5 \mathrm{Ma}$ were obtained for aplitic dyke cross-cutting the granite. The scheelite of magmatic origin in the aplite dyke was identified from petrographic investigation. This demonstrates that W-bearing granites of Early Paleozoic (corresponding to the Caledonian orogensis in the traditional sense) occur in the Nanling Range. This finding has important implications for the ore-forming potential of Paleozoic granites and on the extent of Mesozoic mineralization. Thus it merits performing an intensive study of Paleozoic granites in South China. The occurrences of aplite or microgranite may be an indicative of the Caledonian tungsten granites and associated $\mathrm{W}$ mineralization.
\end{abstract}

scheelite, aplite, Caledonian granite, scheelite-bearing granite, Penggongmiao

Citation: Zhang W L, Wang R C, Lei Z H, et al. Zircon U-Pb dating confirms existence of a Caledonian scheelite-bearing aplitic vein in the Penggongmiao granite batholith, South Hunan. Chinese Sci Bull, 2011, 56: 2031-2036, doi: 10.1007/s11434-011-4526-8

The Nanling Range in South China was successively intruded by Paleoozoic and Mesozoic granites [1,2]. Mineral deposits of $\mathrm{W}, \mathrm{Sn}$, and rare metals are mostly genetically related to the Mesozoic granites. Mineralization also occurred extensively in the Mesozoic [3,4]. Although Paleozoic granites in South China have been investigated in relation to $\mathrm{W}-\mathrm{Sn}$ metallogenesis in previous studies [5-8], some questions still remain regarding these specific types of granites. For example, whether Early Paleozoic, especially corresponding to the Caledonian orogenesis in the traditional sense, mineralized granites exist in the Nanling Range is unknown. This problem has being received close attention from Chinese geologists.

Caledonian granites are plentiful in South China $[9,10]$.

*Corresponding author (email: rcwang@nju.edu.cn)
A granite batholith at Penggongmiao (PGM) in eastern $\mathrm{Hu}-$ nan has an outcrop area of about $900 \mathrm{~km}^{2}$. As early as the 1960s, the PGM granite was assigned to be emplaced in the Caledonian period by a Nanjing University team in the report "Research on different periods of granitoids and their relations to mineralization in South China"[11]. Unfortunately, there was only very limited work on its ore-forming potential. During a new 1:50000 mapping period from 2006 to 2008, geologists of the South-Hunan Geological Survey found a mid-size tungsten deposit composed of scheelite-quartz veins and mineralized greisen near the Zhangjialong village on the southern margin of the PGM granite. On the basis of field sampling in the Zhangjialong mine, we have carried out a zircon U-Pb dating on the W-bearing granite. The results are used to find the genetic relationship between the PGM granite and the $\mathrm{W}$ mineralization. 


\section{Geological setting}

The PGM granite is a large batholith in the Nanling Range. From 1956 to 1961, geologists from the Department of Geology in Nanjing University first assigned this granite as being emplaced in the Early Paleozoic as a response to the Caledonian orogensis in the traditional sense. This was based on its unconformable relationship with the middleDevonian Tiaomajian Formation [1-4]. Using the K-Ar dating technique, Li et al. [12] obtained an emplacement age of 385 Ma for the PGM granite. Petrographically, the PGM batholith can be divided into the following five units:
Tangshi, Manaoxia, Lanxi, Xiangshulong and Enlong [13]. In this paper, these five units were simplified into two stages. The early stage includes the former three units, and consists of coarse-grained porphyritic biotite monzonite granites, which constitute the main phases for $60 \%$ of the entire batholith. The later stage includes the latter two units, and is composed of fine-grained, porphyritic, biotite monzonite granites. This later stage comprises the remaining $40 \%$ of the entire batholith, and is mainly situated in a west to north-east direction with regard to the siliceous fractured zone. The Zhangjialong $\mathrm{W}$ deposit is located on the southern margin of the PGM granite (Figure 1). Inside the mining
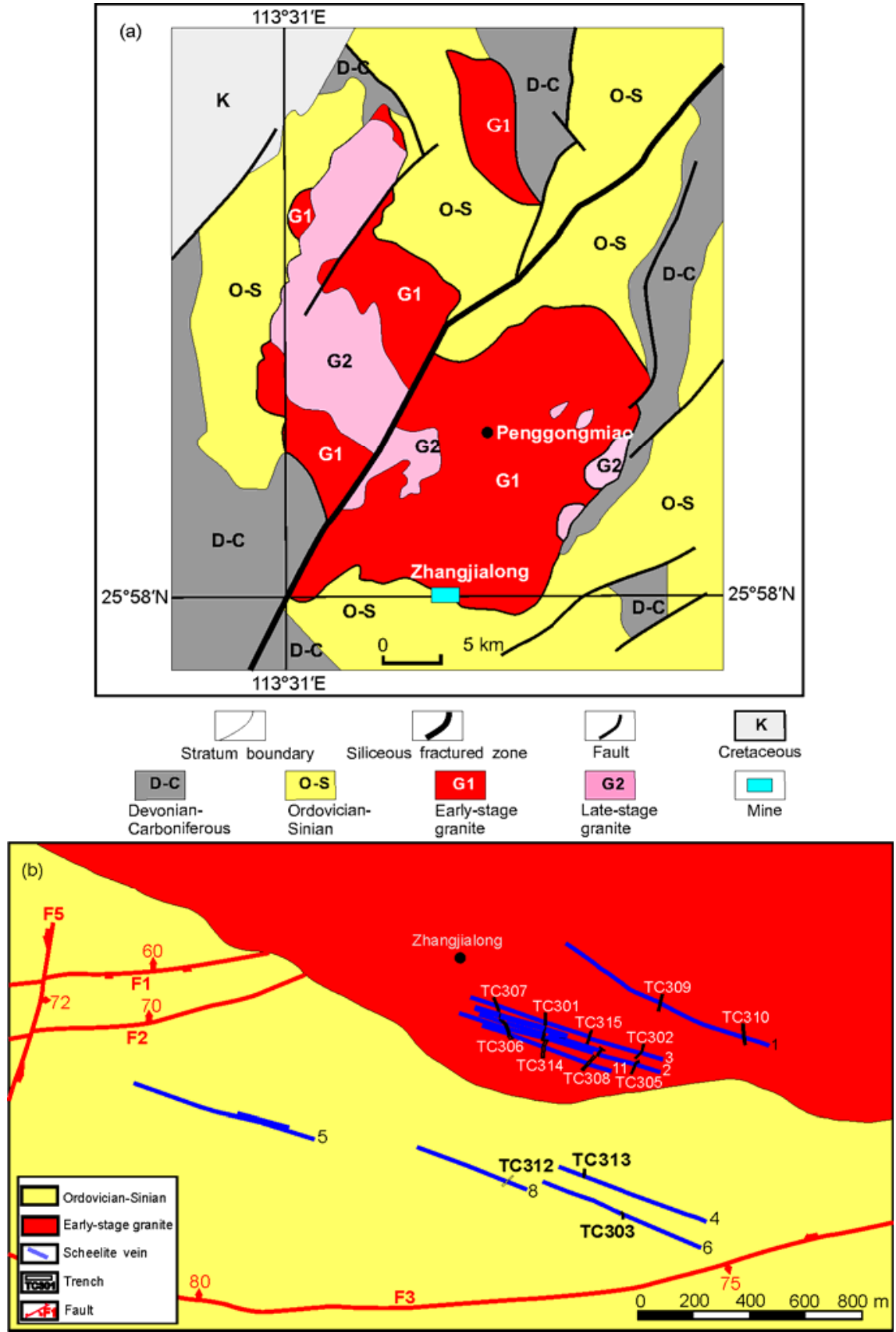

Figure 1 (a) Geologic map of the Penggongmiao granite batholith (simplified after [13]); (b) distribution of scheelite veins in the Zhangjialong area. 
tunnel, 30-50 mm wide aplitic dykes crosscut the porphyritic biotite granite with sharp boundary contacts. Eleven scheelite-quartz veins were found aligned in a NE direction at the southern margin of the PGM granite, in contact with the surrounding rock [5]. These veins vary from 400 to $1800 \mathrm{~m}$ long, but their spatial relationship with the aplitic dyke has not yet been determined because of limited field engineering capacity.

\section{Petrographic features}

The PGM batholith is composed of mainly medium- to coarse-grained biotite granites. It is gray to grey-white with a porphyritic structure and massive texture (Figure 2(a)).

The phenocrysts include oligoclases and microclines. Major minerals include oligoclase, microcline, quartz and biotite. Accessory minerals include apatite, rutile, sphene and zircon.

The aplitic dyke is light gray, and exhibits a fine-grained structure and massive texture (Figure 2(b)). It has a sharp contact with the granite. Major minerals within the aplitic dyke are K-feldspar, albite, quartz and minor muscovite. The accessory minerals are apatite, zircon, ilmenite and scheelite.

\section{Zircon U-Pb dating}

Samples used for zircon U-Pb dating were collected from the Zhangjialong area. Sample ZJL-07 represents a strongly weathered medium-coarse-grained biotite granite collected in the No. 307 trench (Figure 1(b)). Sample ZJL-10 is a fresh, medium coarse-grained biotite granite collected along the highway (Figure 2(a)). Sample ZJL-01 is an aplitic dyke collected at the mine opening entrance (Figure 2(b)). Petro- graphic observations were conducted with the backscattered electron imaging capability on a JEOL JXA8100 Electron Microprobe at State Key Laboratory of Mineral Deposits in Nanjing University. Zircon dating was completed using the LA-ICP-MS method at the Key Laboratory under standard conditions and parameters [14]. Zircon U-Pb isotopic results are given in Table S1, and concordia diagrams are shown in Figure 3.

The U-Pb isotope data for 22 zircon grains from sample ZJL-07 (weathered, medium-coarse-grained, porphyritic biotite granite) is shown in Figure 3(a). Three zircon grains display discordant ${ }^{206} \mathrm{~Pb} /{ }^{238} \mathrm{U}$ ages of $456 \mathrm{Ma}, 423 \mathrm{Ma}$, and $547 \mathrm{Ma}$, respectively. The remaining 19 zircon grains had nearly concordant U-Pb ages arying from 434 to $437 \mathrm{Ma}$, with a weighted mean of $435.3 \pm 2.7$ Ma.

The $\mathrm{U}-\mathrm{Pb}$ isotope data for zircon grains from sample ZJL-10 (fresh, medium-coarse grained, porphyritic biotite granite) is shown in Figure 3(b). Among the 21 analyzed zircon grains, six grains had discordant ${ }^{206} \mathrm{~Pb} /{ }^{238} \mathrm{U}$ ages of 451, 477, 465, 991, 470 and $491 \mathrm{Ma}$. The other 15 gains had relatively uniform concordant $\mathrm{U}-\mathrm{Pb}$ ages of 435 to $438 \mathrm{Ma}$, with a weighted mean of $436.2 \pm 3.1$ Ma.

Twenty-three zircon grains from the aplitic dyke were analyzed for $\mathrm{U}-\mathrm{Pb}$ isotopes (Figure 3(c)). Twenty points were plotted on the concordant curve with ${ }^{206} \mathrm{~Pb} /{ }^{238} \mathrm{U}$ ages ranging from 425 to $428 \mathrm{Ma}$, with a weighted mean of $426.5 \pm 2.5 \mathrm{Ma}$. The ${ }^{206} \mathrm{~Pb} /{ }^{238} \mathrm{U}$ ages of the other three zircons were 501, 468 and $2329 \mathrm{Ma}$, respectively. These ages are clearly older and indicate that the zircons are inherited from source.

According to three groups of zircon $\mathrm{U}-\mathrm{Pb}$ ages, the intrusion ages of the PGM medium- to coarse-grained granite are in a small range of $435.3 \pm 2.7 \mathrm{Ma}$ to $436.2 \pm 3.1 \mathrm{Ma}$. This confirms that this granite is Early Paleozoic in age, corresponding to the Caledonian orogensis in the traditional sense. The zircon $\mathrm{U}-\mathrm{Pb}$ age of $426.5 \pm 2.5 \mathrm{Ma}$ for the aplitic
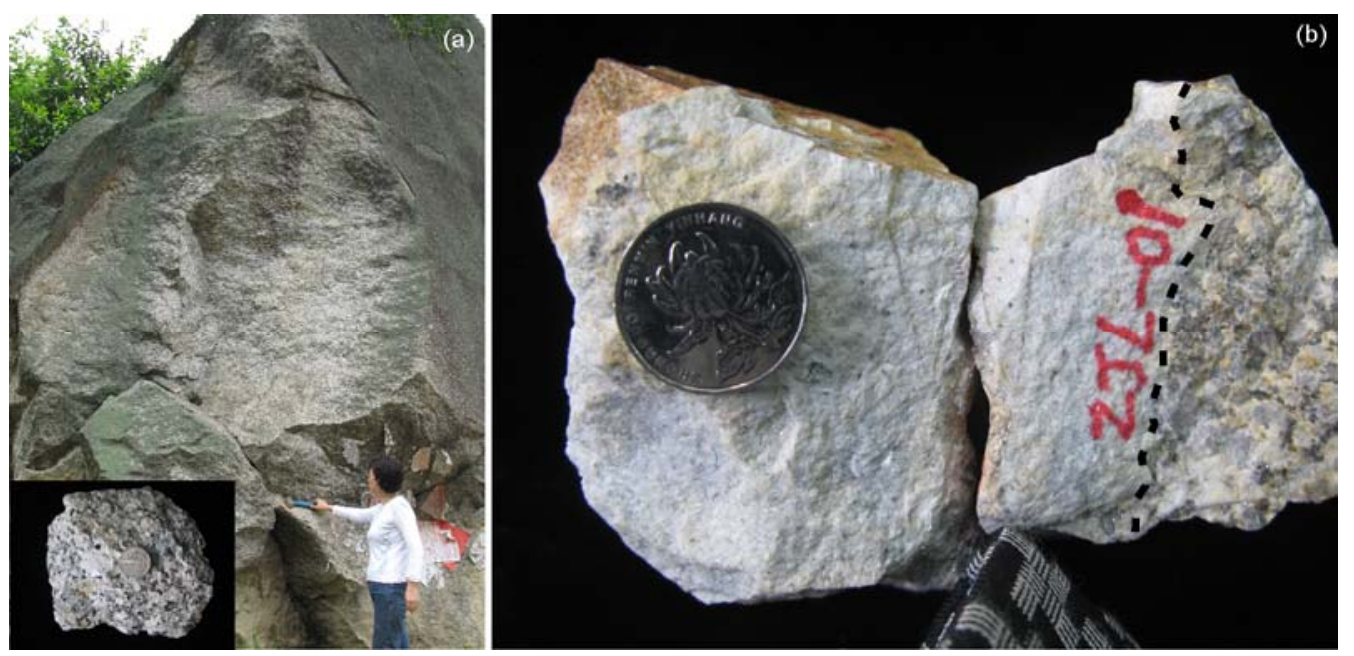

Figure 2 (a) Field photo showing the PGM medium-coarse-grained porphyritic biotite granite with the inset showing the sample collected at the site; (b) aplitic dyke hand samples cross-cutting the main granite. The right sample shows a sharp contact between the aplite and the granite. 

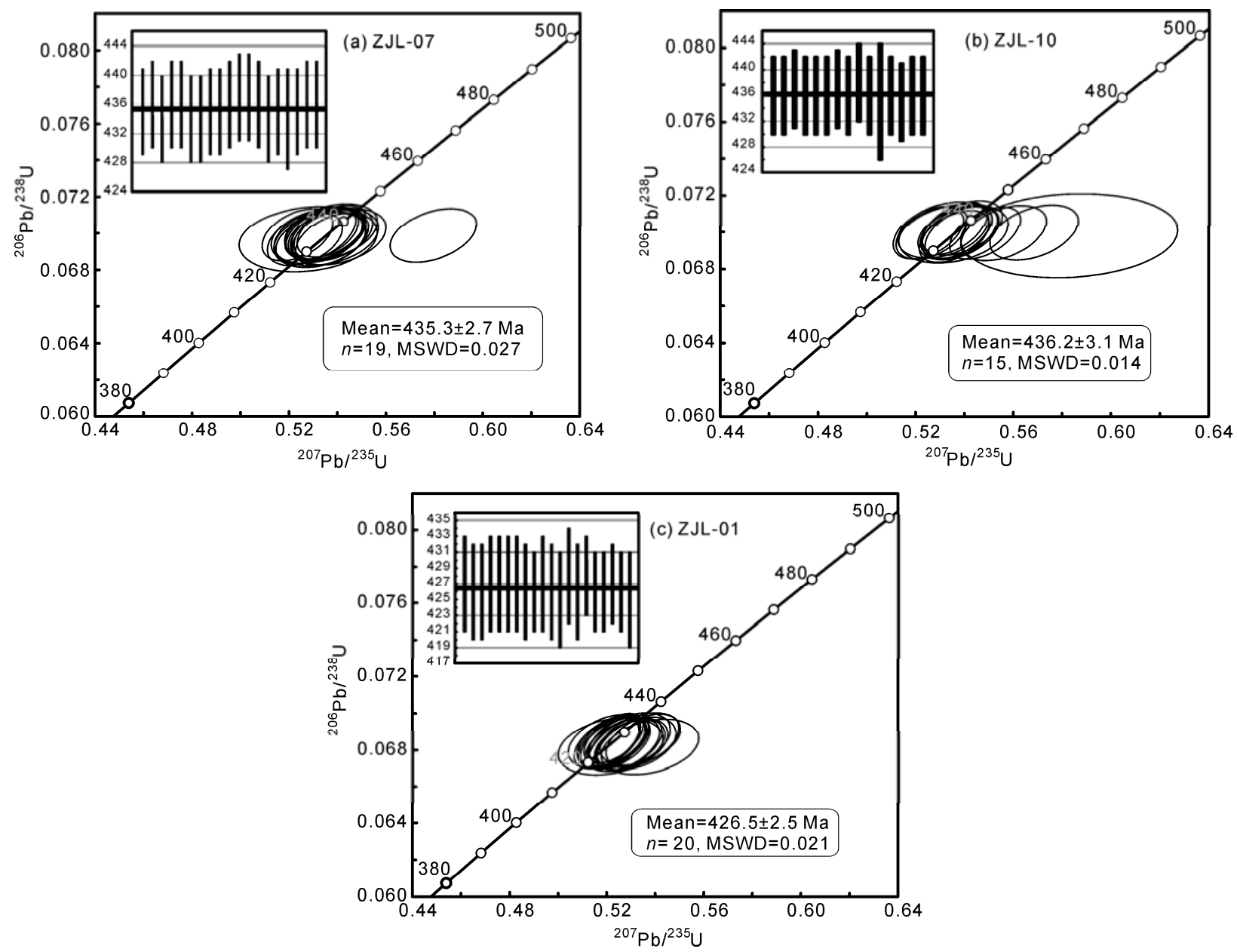

Figure 3 Concordia diagrams of zircon U-Pb data for the Penggongmiao granite batholith. (a) Weathered, medium- to coarse-grained, porphyritic biotite granite (ZJL-07); (b) fresh, medium- to coarse-grained porphyritic biotite granite (ZJL-10); (c) aplitic dyke (ZJL-01).

dyke indicates that the aplite also is a product of Caledonian magmatic activity.

\section{Scheelite in aplitic dyke}

Wolframine and scheelite are two important tungsten minerals. Wolframine can occur as a magmatic mineral in granites [15]. Although scheelite also can occur in granite (e.g. in the Xihuashan tungsten granite, Jiangxi [16], or in the Xuebaoding granite, Sichuan $[17,18])$, direct crystallization of scheelite from granitic magma is very rarely [19]. Scheelite from the PGM granite batholith was investigated with electron-probe backscattered electron imaging. Scheelite only was found in the aplitic dyke. Several scheelite grains were observed in a single probe view (Figure 4(a)). Scheelite grains were all disseminated in the rock and exhibited sharp contacts with rock-forming minerals. In particular, the euhedral 30-micron-sized scheelite grain in Figure 4(b) was encluded within albite, which does not display any alteration phenomena. Scheelite may be closely associated with other accessory minerals (Figure 4(c), (d)). The scheelite of this study is mosaically intergrown with zircon, and no hydrothermal alteration was observed with the neighboring $\mathrm{K}$-feldspar. These petrographic features indicate that scheelite is a direct product of magmatic crystallization from the aplitic dyke.

\section{Conclusions}

LA-ICP-MS zircon U-Pb dating suggests that the PGM medium to coarse-grained biotite granite was emplaced in the Early Paleozoic, corresponding to magmatism of the Caledonian orogensis in the traditional sense. The aplitic dyke is also of the Early Paleozoic U-Pb age. The PGM granite batholith represents multiple episodes of magma intrusions. Scheelite of magmatic origin in the aplitic dyke indicates that high $\mathrm{W}$ enrichment may be reached during the latest stage of magma evolution in the PGM granite batholith.

$\mathrm{Xu}$ et al. [20] did not favor the idea that the Caledonian granites in South China contributed to tungsten, tin and raremetal mineralization because there were no known tungsten or tin deposits in the Caledonian granites and the periphery 

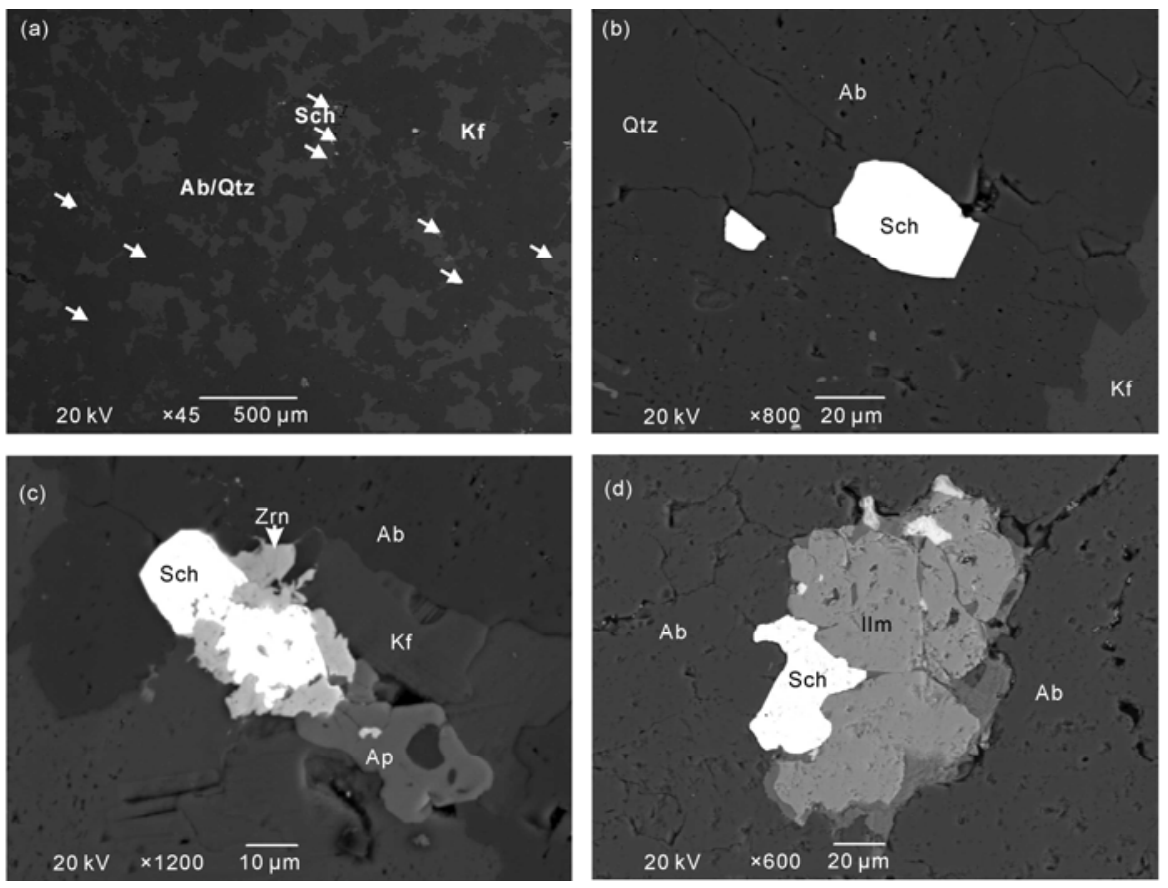

Figure 4 Backscattered electron images of scheelite from the Penggongmiao aplitic dyke. (a) Scheelite grains (arrowed white); (b) euhedral scheelite included in albite; (c) scheelite mosaically intergrown with zircon; (d) scheelite associated with ilmenite. Qtz, quartz; Ab, albite; Kf, K-feldspar; Sch, scheelite; Zrn, zircon; Ap, apatite; Ilm, ilmenite.

at that time. The preliminary results in this study infer that Caledonian W-rich granites exist in the Nanling Range. This first investigation is important to understanding of the ore potential of Paleozoic granites and extensive Mesozoic mineralization in the Nanling Range. In this regards, the granites of Caledonian age should be studied further. Specifically, the occurrence of aplite or microgranite may be an indicative of the presence of Caledonian $\mathrm{W}$-bearing granites and associated mineralization. Further work on aplite may be used to resolve its evolutionary relation to associated granite, and the temporal-spatial and genetic relationships to scheelite quartz veins.

We thank two anonymous reviewers for their constructive reviews, which significantly improved the manuscript. Dr. He Zhenyu is thanked for the preparation of zircon samples. This work was supported by the National Natural Science Foundation of China (40730423), the Ministry of Science and Technology (2007CB411404), the China Geological Survey (1212010632100) and the Ministry of Land and Resources (201011046).

$1 \mathrm{Xu} \mathrm{K}$, Sun N, Wang D, et al. On the origin and metallogeny of the granites in South China. In: Xu K, Tu G, eds. Geology of Granites and Their Metallogenetic Relations. Proceeding of International, Nanjing University. Beijing: Science Press, 1982. 1-3

$2 \mathrm{Li} \mathrm{X} \mathrm{H,} \mathrm{Li} \mathrm{W} \mathrm{X,} \mathrm{Li} \mathrm{Z} \mathrm{X.} \mathrm{On} \mathrm{the} \mathrm{genetic} \mathrm{classification} \mathrm{and} \mathrm{tectonic}$ implications of the Early Yanshanian granitoids in the Nanling Range, South China. Chinese Sci Bull, 2007, 52: 1873-1885

3 Hua R M, Chen P R, Zhang W L, et al. Three major metallogenic events in Mesozoic in South China. Mineral Deposits, 2005, 24: 99107

4 Mao J W, Xie G Q, Guo C L, et al. Spatial-temporal distribution of
Mesozoic ore deposits in South China and their metallogenic settings. Geol J Chin Univ, 2008, 14: 510-526

5 Chen Y C, Mao J W. Ore Deposit Series and Mineralizinghistories in Northern Guangxi. Nanning: Guangxi Science and Technology Press, 1995. 1-433

6 Ma T Q, Bo D Y, Qi G, et al. Zircon SHRIMP dating of the Xitian granite pluton, Chaling, souhthern Hunan, and its geological significance. Geol Bull Chin, 2005. 415-419

7 Fu J M, Wu S C, Xu D M, et al. Reconstraint from Zircon SHRIMP $\mathrm{U}-\mathrm{Pb}$ Dating on the age of magma intrusion and mineralization in Xitian Tungsten-tin polymetallic orefield,eastern Hunan Province. Geol Mineral Resour South China, 2009, 37: 1-7

8 Yang F, Li X F, Feng Z H, et al. ${ }^{40} \mathrm{Ar} /{ }^{39} \mathrm{Ar}$ Dating of Muscovite from Greisenized Granite and Geological Significance in Limu Tin Deposit. J Guilin Univ Tech, 2009, 29: 21-24

9 Sun T. A new map of distribution of granites in South China and its explanatory notes. Geol Bull Chin, 2006, 25: 332-335

10 Zhang F R, Shu L S, Wang D Z, et al. Discussions on the tectonic setting of Caledonian granitoids in the eastern segment of South China. Earth Sci Front, 2009, 16: 248-260

11 Department of Geology (Nanjing University). Research on different periods of granitoids and their relations to mineralization in South China. Internal Report, 1964, 1415: 91-97

12 Li P, Dai T M, Qiu C Y, et al. K-Ar absolute dating of some pegmatites and granites from Inner Mongolia and Nanling Range. Sci Geol Sin, 1963, 1: 1-9

13 Bo D Y, Huang J Z, Ma R Q, et al. Geology and geochemistry of the Silurian Penggongmiao granitic pluton in southeastern Hunan Province and its implication for tectonic setting. Geoscience, 2006, 20: $130-140$

14 Xu X S, Suzuki K, Liu L, et al. Petrogenesis and tectonic implications of Late Mesozoic granites in the NE Yangtze Block, China: Further insights from the Jiuhuashan-Qingyang complex. Geol Mag, 2010, 147: 219-232

15 Tsareva G M, Naumov V B, Kovalenko V I, et al. Magmatic cassiterite, wolframite, columbite, and tungstoixiolite in Volynia chamber 
pegmatites: Data from inclusions in topaz. Doklady Earth Sci, 1995, 331: $175-178$

16 Wang R C, Fontan F, Chen X M, et al. Accessory minerals in the Xihuashan Y-enriched granitic complex, Southern China: A record of magmatic and hydrothermal stages of evolution. Can Mineral, 2003, 41: 727-748

17 Cao Z M, Li Y G, Ren J G, et al. Geologic and geochemical features of the volatile-rich ore fluid and its tracing and dating in the Xuebaoting beryl-scheelite vein deposit China. Sci China Ser D-Earth Sci, 2002, 32: 719-729

18 Liu Y, Deng J, Li C F, et al. REE composition in scheelite and scheelite Sm-Nd dating for the Xuebaoding W-Sn-Be deposit in Sichuan. Chinese Sci Bull, 2007, 52: 2543-2550

19 Linnen R L, Cuney M. Granite-related rare-element deposits and experimental constraints on Ta-Nb-W-Sn-Zr-Hf mineralization. In: Linnen R L, Samson I M, eds. Rare-Element Geochemistry and Mineral Deposits: Geological Association of Canada. GAC Short Course Notes, 2005, 17: 45-67

$20 \mathrm{Xu} \mathrm{K} \mathrm{Q}$, Sun N, Wang D Z, et al. Investigation on the polycyclic granite intrusions of southern China, with special notice on their ages of intrusions, distribution, characteristics, and their genetic relations to mineral deposits. Acta Geol Sin, 1963, 43: 141-155

Open Access This article is distributed under the terms of the Creative Commons Attribution License which permits any use, distribution, and reproduction in any medium, provided the original author(s) and source are credited.

\section{Supporting Information}

Table S1 LA-ICP-MS U-Pb isotope data of zircon grains from the Penggongmiao granite and coexisting aplitic vein

The supporting information is available online at csb.scichina.com and www.springerlink.com. The supporting materials are published as submitted, without typesetting or editing. The responsibility for scientific accuracy and content remains entirely with the authors. 